\title{
Age-induced apoptosis in the male genital tract of the mouse
}

\author{
M Jara, R Carballada and P Esponda \\ Centro de Investigaciones Biológicas, CSIC, Velázquez 144, 28006-Madrid, Spain \\ Correspondence should be addressed to Pedro Esponda; Email: esponda@cib.csic.es
}

\begin{abstract}
We have examined the effects of ageing on the increase in apoptotic cells numbers in the male genital tract of the house mouse (Mus musculus). We have found that not all organs have the same response. There is an induction of apoptosis in both the epididymis and ventral prostate. However, seminal vesicles and other prostatic lobes remain unaffected. Apoptosis was assessed by several methods: TUNEL, detection of the active fragment of caspase-3 and the pattern of DNA fragmentation on agarose gels. This increase in apoptosis is related to the fall in testosterone levels, although there is only a partial decrease in androgen receptor (AR). AR is still present in all tissues and only moderately reduced in the epididymis and ventral prostate. A more intense increase of lipofuscin granules, which may be indicative of oxidative stress, occurred in these tissues. Finally, testosterone supplementation reverses the changes (both in apoptosis and lipofuscin content in the tissue), suggesting a role of androgens in these processes.

Reproduction (2004) 127 359-366
\end{abstract}

\section{Introduction}

Ageing has different effects on the reproductive tract. In the testes, spermatogenesis and steroidogenesis decrease with old age, as described in ageing laboratory rats (Levy et al. 1999, Zirkin \& Chen 2000). In addition, in the epididymal epithelium, some striking segment-specific changes occur at the histological and biochemical levels prior to the major loss of spermatogenesis. These changes include some ultrastructural features which are characteristic of ageing, such as accumulation of lipofuscin granules, a dramatic increase in the thickness of the basement membrane and the number of halo cells (Serre \& Robaire 1998), and changes in the junctional complexes between epithelial cells (Levy \& Robaire 1999). In addition, changes in the expression of genes related to oxidative stress in the epididymis due to age have also been described (Jervis \& Robaire 2002). Changes in gene expression related to ageing include the decrease of several mRNAs, such as the 5 alpha-reductase isozymes and proenkephalin, that occurs in the epididymis between 6 and 12 months of age (Viger \& Robaire 1995). In fact, this decrease is the earliest marker for ageing in the male reproductive tract of the Brown Norway rat. Male accessory sex glands also experience changes. The secretory activity of the ventral prostate decreases and in the prostatic cells, supra- and paranuclear pleomorphic lysosomes can be observed (Zirkin \& Strandberg 1984).
Apoptosis is an important physiological process that has been associated with ageing (Warner 1999, Higami \& Shimokawa 2000). It is defined by a set of morphological and biochemical changes at different cellular levels (Wyllie et al. 1980), and the result is a physiological elimination of unwanted cells, leaving the surrounding tissue untouched. In relation to ageing, apoptosis has a primary negative effect by destroying essential and often irreplaceable cells, but it also acts to elimination dysfunctional cells and protect the organs against cancer or hypertrophia (Warner et al. 1997).

In the testes, apoptosis increases with age, producing an accelerated germ cell loss (Wang et al. 1999, Kimura et al. 2003). This might be related to the fall in androgen levels (Steiner et al. 1984) and/or an increase in oxidative stress in the tissue (Samanta et al. 1999). On the other hand, these changes also occur in the epididymis and other reproductive organs, so it is not unreasonable to think of an increase in apoptotic indices in the ageing male tract. For this reason, we have examined the induction of apoptosis in the epididymis and male accessory sex glands in the senile mouse. We have estimated apoptotic indices and looked for a role of oxidative stress in the process. In addition, we studied the effects of testosterone administration in reversing age-induced apoptosis. 


\section{Materials and Methods}

\section{Animals}

All male mice used in the experiments were CD-1 males bred in our colony. We had three groups. Group 1 was formed by six young ( 3 months old) mice and group 2, by 21 old ( 2 years old) males. In addition, six old mice received daily intramuscular injections of testosterone $(5 \mu \mathrm{g} / \mathrm{ml})$ for 2 weeks before death. They were assigned to group 3. The animal protocol used was covered by Law 223/88 on Animal Protection of Spain, and the European Union Agreement about Vertebrate Animal Protection (3/18/1986), and it has been approved by the CSIC ethics committee.

\section{Testosterone measurements}

Blood was obtained by cardiac puncture from the animals previously anesthetized by an intraperitoneal injection of a mixture of ketamine (50 mg Ketolar, Parke-Davis, Barcelona, Spain) and Rompún (Bayer, Leverkusen, Germany). Typically, $0.8 \mathrm{ml}$ of Ketolar was mixed with $0.15 \mathrm{ml}$ of Rompún and $9 \mathrm{ml}$ of $\mathrm{PBS}$, and $0.8 \mathrm{ml}$ of the mixture was injected into the mouse. Clots were left for $1-2 \mathrm{~h}$ at $4^{\circ} \mathrm{C}$, and then supernatants were centrifuged at $16000 \mathrm{~g}$. Serum was stored frozen at $-20^{\circ} \mathrm{C}$ until use. Testosterone values were measured in triplicate by radioimmunoassay using the Testosterone/Dihydrotestosterone Biotrak Assay kit manufactured by Amersham (Arlintong Heights, IL, USA). Sensitivity of the method was of $6.25 \mathrm{pg}$ per tube (coefficient of intra-assay variation was $4 \%$ and coefficient of inter-assay variation was less than $12 \%$ ).

\section{Detection of DNA fragmentation}

After the animals were bled to death, the male genital tract was isolated and dissected free of fat. For fixation, pieces of the male ducts (caput, corpus and cauda epididymidis) and the various accessory sex glands (seminal vesicles, coagulating glands, and dorsolateral and ventral lobes of the prostate) were immersed in $4 \%$ paraformaldehyde in PBS, and kept for $1-2 \mathrm{~h}$ at room temperature, and then overnight at $4{ }^{\circ} \mathrm{C}$. In the caput epididymidis, segments II and III described by Abe et al. (1983) for the mouse, were analyzed. Samples were subsequently washed and embedded in paraffin-wax following standard procedures. Thin sections $(5 \mu \mathrm{m})$ were obtained using a Leica microtome, mounted on slides, cleared with xylol, hydrated, and stained with Weigert's iron hematoxylin solution (Clark 1981). The stained sections were subsequently washed in distilled water, counterstained with saturated picric acid to increase contrast, dehydrated, mounted with Entellan (Merck, Whitehouse Station, NJ, USA) and scored under bright-field optics for the presence of apoptotic cells. Apoptosis was defined according to the presence of condensed chromatin granules in the nucleus.
Several series of sections were used for detection of DNA fragmentation in situ using the TUNEL (Terminal transferase dUTP nick-end labeling) detection kit supplied by Roche (Basel, Switzerland), following the manufacturer's instructions. Nuclei were counterstained with a solution $10 \mu \mathrm{M}$ of Hoechst 33342 (Sigma, St Louis, MO, USA). Results were assessed under epifluorescence using the appropriate filters.

The percentages of apoptotic cells were determined by counting randomly selected areas with at least 3000 cells. There were three animals per groups; thus, a minimum of 9000 cells per group was scored.

In addition, samples from the different tissues were freshly isolated, cut into small pieces and digested with collagenase $(10 \mathrm{mg} / \mathrm{ml}$ in RPMl 1640 medium) for $30 \mathrm{~min}$ at $37^{\circ} \mathrm{C}$. The tissue fragments were pelleted by centrifugation at $1500 \mathrm{~g}$ for $5 \mathrm{~min}$, and fresh collagenase solution was added. After a new 30-min digestion, the cells were washed 2-3 times, and the pellet was subjected to extraction of extrachromosomal DNA, as described by Fabregat et al. (1996). Total DNA extracts isolated from young and old tissues were labeled with ${ }^{32} \mathrm{P}-\mathrm{dCTP}$ using terminal transferase (Roche, Basel, Switzerland) and cleaned using the QIAquick Nucleotide Removal Kit (Qiagen, Valencia, CA, USA). The labeled DNA was resolved by electrophoresis through $1.5 \%$ agarose gel at $40-45 \mathrm{~V}$ for $5 \mathrm{~h}$. Then, it was dried and exposed to an X-OMAT-AR (Kodak, Rochester, NY, USA) to visualize the DNA ladder.

\section{Statistical analyses}

All data are expressed as means \pm S.E.M. Statistical differences among groups were examined by one-way ANOVA followed by Student's $t$-test $(P<0.05)$.

\section{Caspase-3 detection}

Samples of the tissues were snap frozen in liquid nitrogen and sectioned using a cryostat. The sections $(5-7 \mu \mathrm{m})$ were fixed for $10 \mathrm{~min}$ in an ice-cold mixture of acetone and methanol (1:1) and then air dried and stored frozen until use. The non-specific binding sites were blocked by

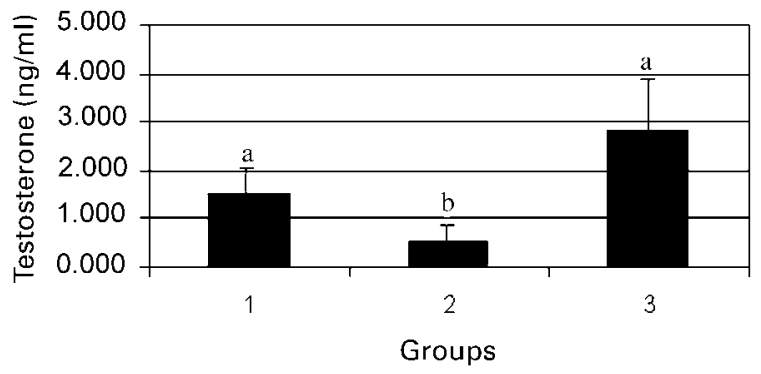

Figure 1 Serum testosterone values in the different groups (Group 1: young ( 3 months old). Group 2: aged (2 years old). Group 3: aged plus testosterone. For group 1, $n=6$; for 2, $n=15$; and for $3, n=6$. Values are expressed as means \pm S.E.M. Different letters indicate statistically significant differences $(P<0.05)$. 

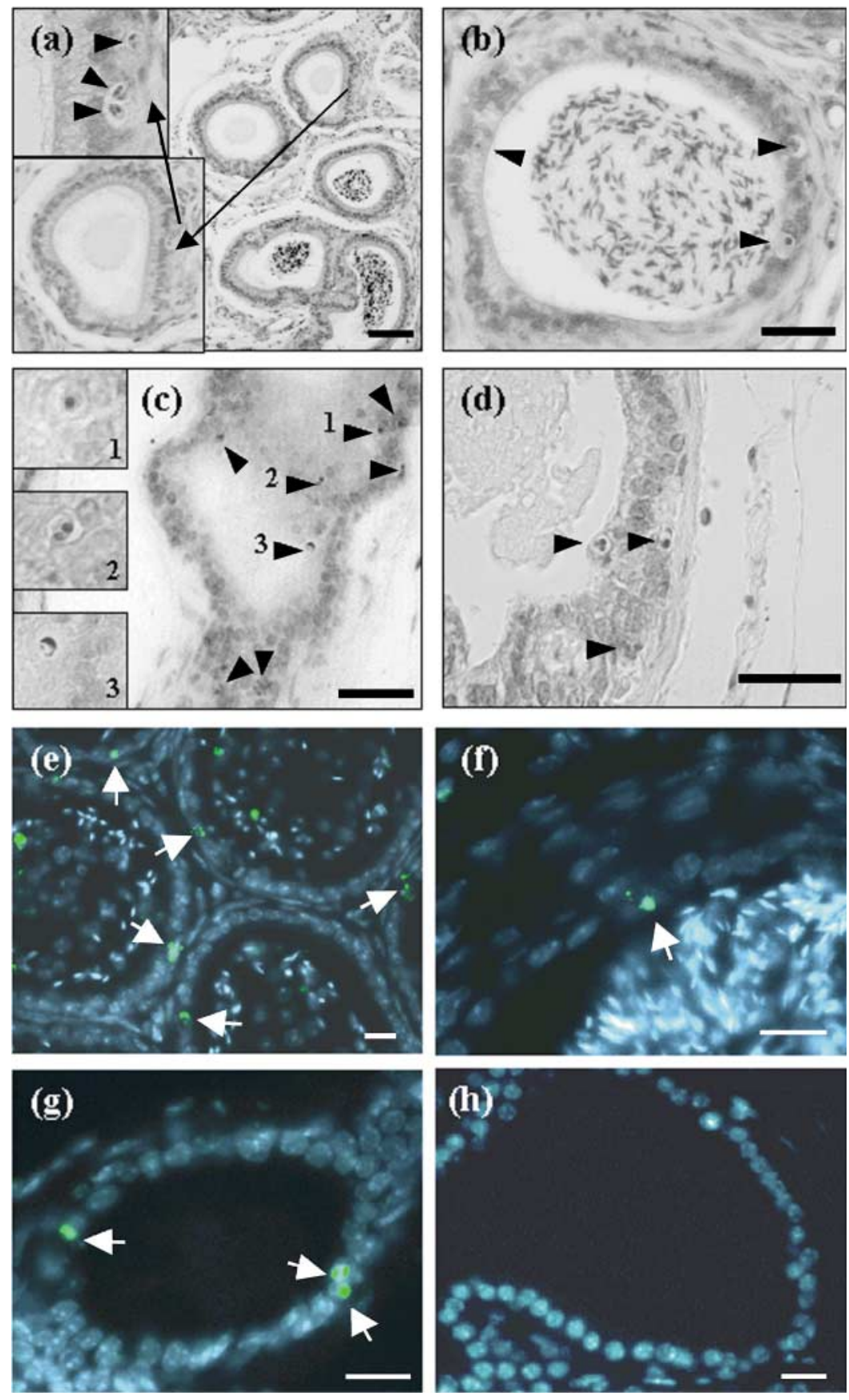

Figure 2 Detection of apoptosis in epithelia by hematoxylin staining $(\mathrm{a}-\mathrm{d})$ and TUNEL $(\mathrm{e}-\mathrm{h})$. (a) Caput epididymidis from an old mouse (group 2). The arrowheads indicate apoptotic bodies. Bar, $20 \mu \mathrm{m}$. (b) Detail of a tubule of the caput epididymidis from an old mouse (group 2). Several apoptotic bodies, indicated by arrowheads, can be distinguished. Bar, $20 \mu \mathrm{m}$. (c) Ventral prostate from a mouse from group 2. Apoptotic nuclei are indicated by arrowheads. Three of them $(1,2,3)$ are magnified in the insets. Bar, $20 \mu \mathrm{m}$. (d) Ventral prostate from an old mouse (group 2). Several apoptotic bodies (arrowheads) are seen. (e) Caput epididymidis of an old mouse stained by TUNEL. The positive reaction is visualized in green. Nuclei are counterstained with Hoechst 33342 and are observed in blue. Several apoptotic nuclei are indicated by arrows. Bar, $10 \mu \mathrm{m}$. (f) Detail of an apoptotic cell (arrow) in the epididymal epithelium from an old mouse. Bar, $10 \mu \mathrm{m}$. (g) Section of the ventral prostate from an animal from group 2 stained by TUNEL. Several apoptotic nuclei are indicated by arrows. Bar, $10 \mu \mathrm{m}$. (h) Ventral prostate from an animal from group 3. No apoptotic nuclei can be seen. Bar, $10 \mu \mathrm{m}$. incubation for $1 \mathrm{~h}(\mathrm{RT})$ in $3 \% \mathrm{BSA}$ in PBS. The primary antibody was an anti-ACTIVE Caspase polyclonal antibody (Promega, Madison, WI, USA) that specifically recognizes the cleaved active form of caspase- 3 in human and mouse used at a concentration of $2 \mu \mathrm{g} / \mathrm{ml}$. An anti-rabbit IgG conjugated to FITC diluted 1:200 in PBS was used as the secondary antibody. The positive reaction was visualized in a Nikon fluorescence microscope. Images were recorded using a microscope equipped with a CCD system (200A, Polytronics, Emsworth, UK).

\section{Androgen receptor expression}

Androgen receptor expression was assessed by immunohistochemistry and Western blot, using as the primary antibody a polyclonal antibody, PG-21 (Upstate Biotechnology, Lake Placid, NY, USA). For Western blots, the tissues were homogenized and extracted with RIPA buffer $(50 \mathrm{mM}$ Tris, $150 \mathrm{mM} \mathrm{NaCl}, 1 \% \mathrm{NP} 40,1 \%$ sodium deoxycholate, $1 \%$ SDS, 2 mM EDTA, $\mathrm{pH}$ 7.5) containing protease inhibitors $(10 \mathrm{mM}$ PMSF, leupeptin, antipain, chymostatin and pepstatin at $1 \mu \mathrm{g} / \mathrm{ml}$ and benzamidine at 
$10 \mu \mathrm{g} / \mathrm{ml}$ ) for $1 \mathrm{~h}$ in ice. The volume was $100 \mu \mathrm{l}$ for every organ with the exception of the seminal vesicle, for which $200 \mu \mathrm{l}$ were used. Protein concentration in the different samples was estimated using the BioRad Protein Assay kit (BioRad, Hercules, CA, USA). A total of $400 \mu \mathrm{g}$ of proteins was loaded in $10 \%$ acrylamide gels and blotted onto $0.2 \mu \mathrm{m}$ pore nitrocellulose filters. Nonspecific reaction was blocked by 1 -h incubation in blocking reagent (Roche, Basel, Switzerland). Primary antibody was used at $1 \mu \mathrm{g} / \mathrm{ml}$. Secondary antibody was an anti-rabbit IgG conjugated to alkaline phosphatase (KPL, Gaithersburg, MD, USA) diluted 1:1000 in PBS. The positive reaction was detected using a chemoluminiscent substrate CDPStar (Roche), following manufacturer's instructions.

For immunocytochemistry, samples of the frozen tissues were sectioned using a cryostat. The sections $(5-7 \mu \mathrm{m})$ were fixed for $10 \mathrm{~min}$ in an ice-cold mixture of acetone and methanol $(1: 1)$ and then air dried and stored frozen until use. The non-specific binding sites were blocked by incubation for $1 \mathrm{~h}(\mathrm{RT})$ in $3 \%$ BSA in PBS. The primary antibody (PG-21) was used at a concentration of $2 \mu \mathrm{g} / \mathrm{ml}$. An anti-rabbit IgG conjugated to FITC diluted 1:200 in PBS was used as the secondary antibody. The positive reaction was visualized in a Nikon fluorescence microscope. Images were captured using a microscope equipped with a CCD system (200A, Polytronics, Emsworth, UK).

\section{Detection of lipofuscin}

Lipofuscin was detected by the Popper's method (Kasten 1981). Briefly, samples from the tissues were snap frozen in liquid nitrogen and were used to obtain $10 \mu \mathrm{m}$ cryosections that were directly scored under epifluorescence using a $580 \mathrm{~nm}$ filter to detect autofluorescent granules.

\section{Results}

\section{Testosterone measurements}

The testosterone values are indicated in Fig. 1. As can be observed, the old mice have a significantly lower concentration of testosterone in their blood than the young ones or those injected with testosterone.

\section{Detection of DNA fragmentation in situ}

We observed apoptotic cells in the epididymides and ventral prostates of the old mice (Fig. $2 a-d$ ). The use of the TUNEL technique allowed us to assess whether these cells were indeed undergoing apoptosis (Fig. 2e-h). There were no significant numbers of apoptotic cells either in the dorsal and cranial lobes of the prostate or in the seminal vesicles. On the other hand, apoptosis was abolished in the epididymis and ventral prostate by testosterone treatment. These results were confirmed by caspase- 3 detection. The active fragment of the enzyme was detected in epithelial cells from both the epididymis and ventral prostate (Fig. 3).

The apoptotic indices are indicated in Fig. 4 ( $a$ and b). The highest values were found in the caput epididymidis. Those found in the corpus and cauda were lower and similar to those found in the ventral prostate. Testosterone supplementation resulted in the indices falling to control values.

\section{DNA framentation in agarose gels}

Results are shown in Fig. 5. Both the epididymis and ventral prostate reveal an obvious DNA ladder indicative of DNA fragmentation. This was reversed by testosterone treatment. There is also a ladder in tissue from young
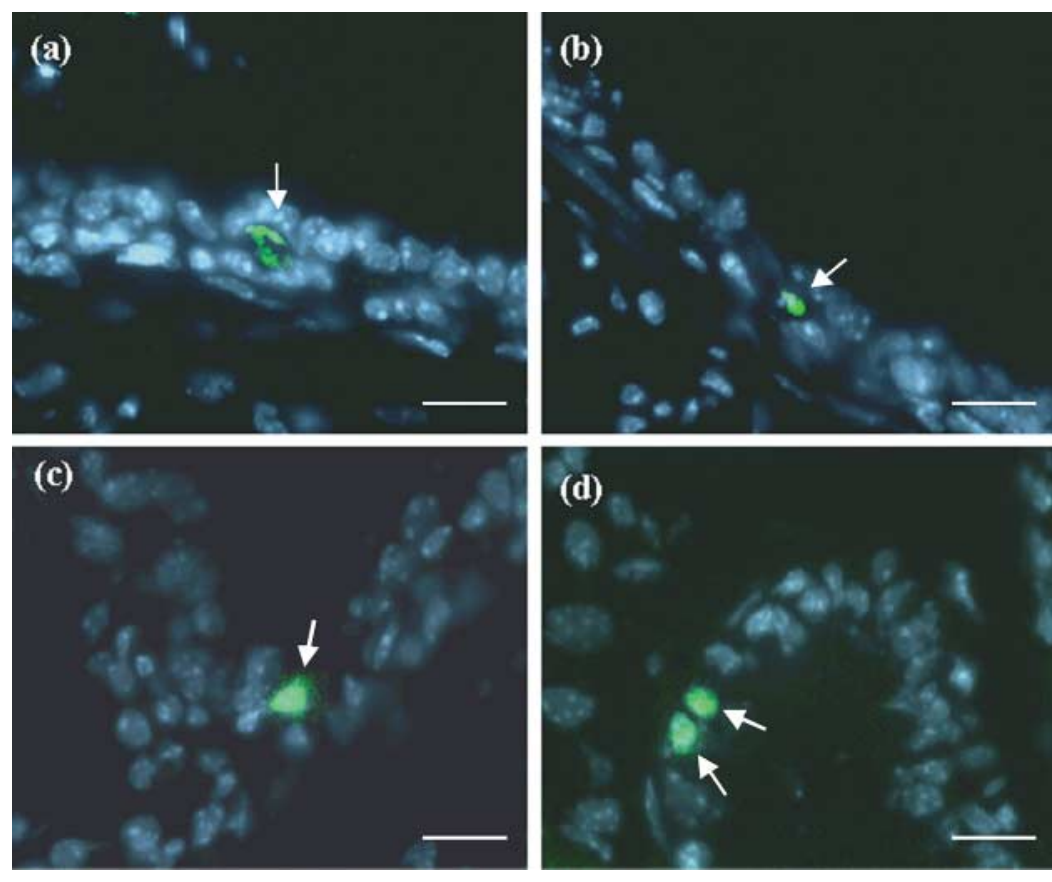

Figure 3 Detection of the active fragment of caspase-3 in the different tissues in aged animals (group 2). The positive reaction is visualized in green. Nuclei are counterstained with Hoechst 33342 and are observed in blue. (a) caput epididymidis, (b) cauda epididymidis, (c, d) ventral prostate. The bars represent $10 \mu \mathrm{m}$. 
(a)

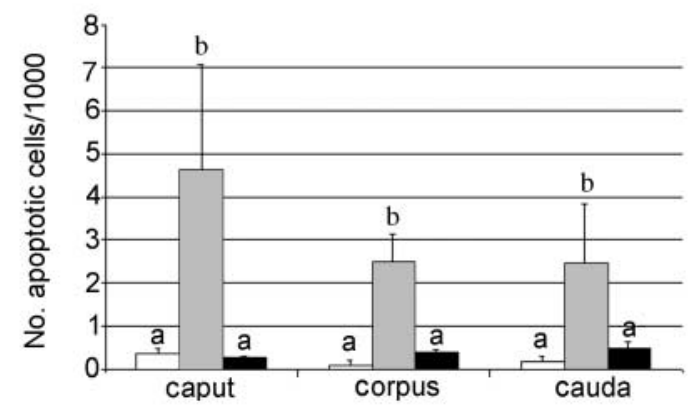

(b)

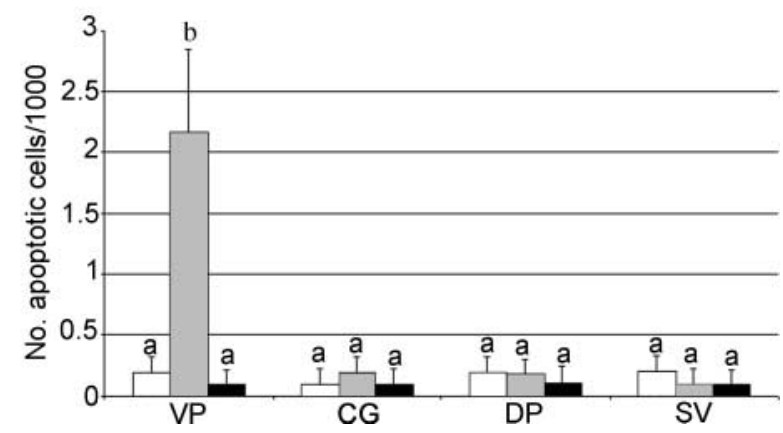

Figure 4 (a) Number of apoptotic cells in the different regions of the mouse epididymis of the different groups. Group 1 (open bars): young ( 3 months old). Group 2 (gray bars): aged (2 years old). Group 3 (black bars): aged plus testosterone. Values are expressed as means \pm S.E.M. Different letters indicate statistically significant differences $(P<0.05)$. (b) Number of apoptotic cells in the different male accessory sex glands of the different groups. For the three groups, $n=3$. Values are expressed as means \pm S.E.M. Different letters indicate statistically significant differences $(P<0.05)$. VP, ventral lobe of the prostate; CG, coagulating glands; DP, dorsolateral lobe of the prostate; SV, seminal vesicles.

animals, but it is faint, representing the background levels of normal apoptosis on every organ. In both dorsal prostate and seminal vesicles, old animals show comparable levels of apoptosis to the young ones (Fig. 5c and d).

\section{Androgen receptor detection}

The androgen receptor was localized in all tissues analysed. The levels detected by Western blots were not very different among groups, although a lower amount occurred in the epididymides and ventral prostates of the senile mice. No differences were detected by immunocytochemistry among young and old animals. All the organs showed androgen receptors in a nuclear localization (data not shown).

\section{Detection of lipofuscin granules}

We detected lipofuscin granules in all organs, but they were more evident in those organs that presented apoptosis (that is, epididymis and ventral prostate), as can be
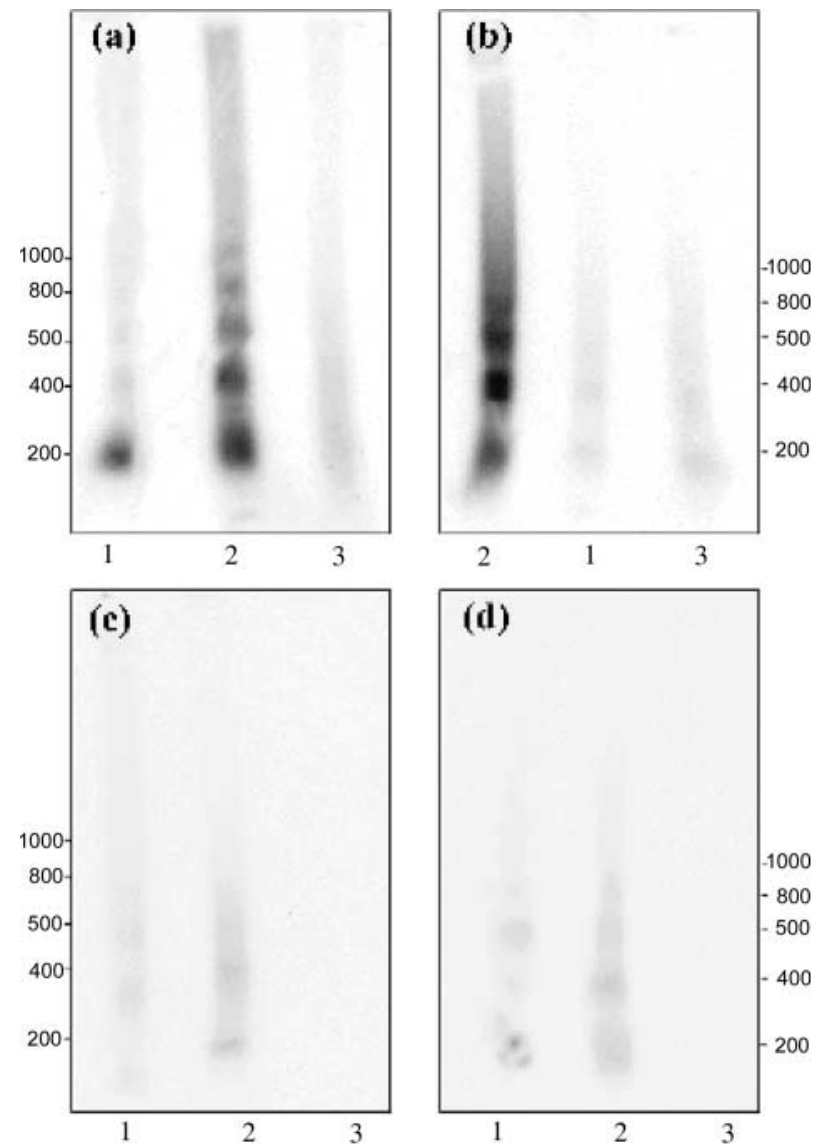

Figure 5 Analysis of DNA fragmentation in different tissues studied on agarose gels. Total extranuclear DNA obtained as described in the text from epididymis (a), ventral prostate (b), seminal vesicles (c) and dorso-lateral prostate $(\mathrm{d})$ was resolved on a $1.5 \%$ agarose gel and exposed to X-OMAT AR Kodak film to visualize the DNA ladder. Numbers at the bottom of each lane indicate the group. Numbers on the right and left represent the molecular size in $\mathrm{kb}$ of the markers (Roche No XIV).

seen in Fig. 6. The content of lipofuscin granules was decreased in all cases by testosterone treatment.

\section{Discussion}

It is well known that ageing affects reproduction in the male. Old age brings about degenerative changes in the testes. Apoptosis has been shown to play a role in these changes (Wang et al. 1999, Kimura et al. 2003). Here we showed that not only the gonads but also the epididymis and the ventral prostate do undergo an increase in apoptotic rates. The present results after using TUNEL and the ladder procedure, the existence of apoptotic bodies, the isolated distribution of positive cells and the absence of inflammatory reaction, clearly indicates that positive cells are apoptotic. The changes in the epididymis are not surprising; since the epididymis depends on androgens and testicular factors, it may well be reflecting the changes in the testes. Moreover, there was also a regional response, and apoptotic indices were higher in the caput 

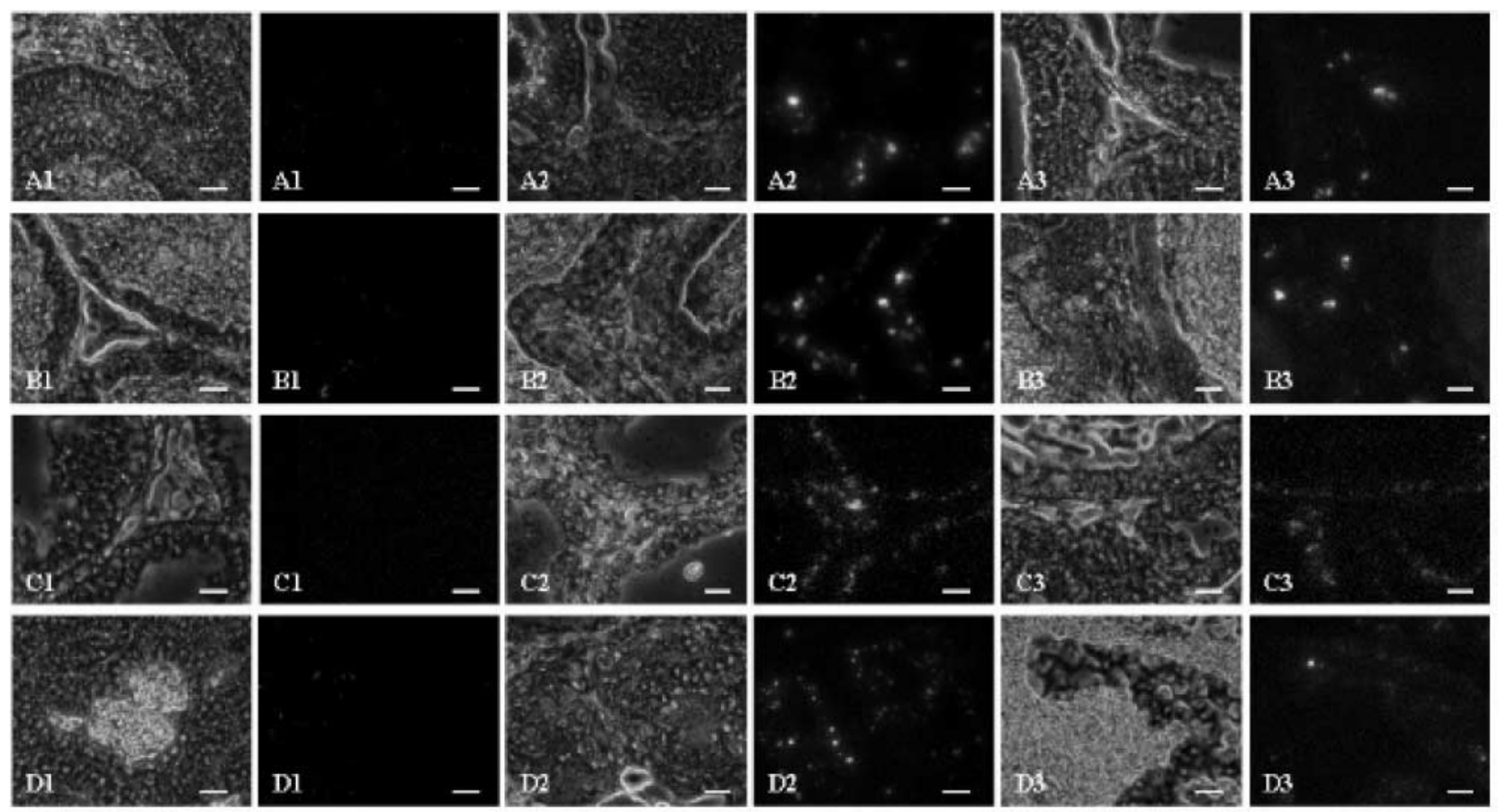

Figure 6 Detection of lipofuscin granules in the caput epididymidis (A1-A3), the cauda epididymidis (B1-B3), the ventral prostate (C1 -C3), and the seminal vesicles (D1-D3). Numbers indicate the different groups: 1) young, 2) aged, 3) aged plus testosterone. Each case is observed under phase contrast (at the left) and fluorescence (at the right). Lipofuscin granules are prominent in the epididymis and ventral prostate of old animals. Bars, $10 \mu \mathrm{m}$.

epididymis that in the corpus or cauda. This regional response is also evident in the epididymis of castrated rats (Adams 1984). This was explained as a reflection of the differences in androgen concentration in the luminal fluids along the epididymis (Fan \& Robaire 1998). It may be the same situation in the old mice, since the old testes in the rat secrete much less testosterone (Turner et al. 1984), and actually our RIA analyses in the mice showed a considerable decrease in androgen content. Of all the accessory glands examined, only the ventral prostate showed signs of apoptosis. Interestingly, this is the only prostatic lobe that shows castration-induced cell death (Chen et al. 1994). However, castration induces apoptosis in the seminal vesicles (Tsuji et al. 1998), and we did not see any apoptosis in the tissues from old animals. We must consider, however, that, although the testosterone levels fall, they are still measurable, and when the androgen receptor levels were examined, there were significant amounts of them with normal nuclear localization. Thus, it is likely that only the most sensitive organ, the ventral prostate, can react to the changes. That the androgen withdrawal was ultimately responsible for the induction of apoptosis is supported by the fact that androgen supplementation abolished the age-induced apoptosis in all epididymal segments and the ventral prostate.

The lipofuscin detection deserves some special comment. Lipofuscin is also called age pigment (Brunk et al. 1992). Oxidative stress, as well as diminished activity of lysosomal proteolytic enzymes, is known to induce lipofuscin accumulation in a variety of cell types (Banerjee et al. 1995). Lipofuscin cannot be degraded and accumulates with age, being at least partially responsible for the senescent phenotype in the cell (Terman \& Brunk 1998). Interestingly, we saw larger lipofuscin deposits in the epididymis and the ventral prostate than in the other prostatic lobes and other accessory sex glands. Moreover, the lipofuscin contents decreased after testosterone treatment. It is possible that this decrease is due to a dilution effect caused by an increase in cell size or the presence of new cells generated by mitosis which occurs after testosterone treatment. Thus, lipofuscin contents match the apoptotic indices in the tissue. This could indicate that both phenomena are closely related. In fact, lipofuscin granules have been seen in the diaphragm muscles of the $X$ chromosome-linked muscular dystrophic $(\mathrm{mdx})$ mice in cells undergoing apoptosis (Sitte et al. 2000), a finding which supports this hypothesis. Moreover, in the dog prostate, apoptotic cells that appear after castration are loaded with lipofuscin granules (Nakae et al. 2001). Oxidative stress could be the link to both processes. Testosterone has been shown to be a protective agent against cellular damage induced by oxidative stress in cerebellar neurons (Ahlbom et al. 2001, Niu et al. 2001). On the other hand, oxidative stress influences the accumulation of lipofuscin granules (Ahlbom et al. 1999) and can induce apoptosis in a variety of cell types (Brunk \& Terman 2002, Curtin et al. 2002), so it is possible that the fall in testosterone can induce a joint increase in oxidative stress and apoptosis. 
One of the most surprising facts that deserves some comment is how testosterone supplementation was able to suppress the deleterious effects of old age in the male tract, at least regarding apoptosis. Testosterone is a wellknown proliferative agent in the prostate both in vitro (Kagan et al. 2002) and in vivo (Silva et al. 2001). This suggests that testosterone treatment could be effective in restoring some of the reproductive organs. In fact, supplementation with low doses of testosterone has some beneficial effects on the male rat, such as preventing the loss of body and bone mass (Waltregny et al. 2001). Moreover, androgen supplementation in the old rat is partially able to restore sperm numbers in the epididymis (Vanderschueren et al. 2000), suggesting that the male tract in the old animal is able to respond to exogenous stimulation. In old men, the benefits of testosteronereplacement therapy are still under evaluation (Gooren 2003, Morley \& Perry 2003). Anticipated risks lie principally with the prostate and the cardiovascular system. The risks with regard to prostate disease are often over-rated; nevertheless, there is an impending need of more data (Tenover 1999, Gooren 2003).

In summary, old age induces apoptosis in the epididymis and ventral prostate, which seems to be caused by the fall of testosterone levels and is probably related to an increase in the oxidative stress in the tissues. More detailed analyses are needed to elucidate the precise molecular mechanisms involved in this age-induced apoptosis.

\section{Acknowledgements}

This work was partially supported by a grant BCM2000-0899 from the DGICYT (Spain). Marco Jara is grateful to the AECI (Spain) for financial support.

\section{References}

Abe K, Takano H \& Ito S 1983 Ultrastructure of the mouse epididymal duct with special reference to the regional differences of the principal cells. Archivum Hislogicum Japonicum 46 51-68.

Adams CE 1984 Reproductive senescence. In Reproduction in mammals, vol 4, pp 210-233. Eds CR Austin \& RV Short. Cambridge: Cambridge University Press.

Ahlbom E, Grandison L, Bonfoco E, Zhivotovsky B \& Ceccatelli S 1999 Androgen treatment of neonatal rats decreases susceptibility of cerebellar granule neurons to oxidative stress in vitro. European Journal of Neuroscience 11 1285-1291.

Ahlbom E, Prins GS \& Ceccatelli S 2001 Testosterone protects cerebellar granule cells from oxidative stress-induced cell death through a receptor mediated mechanism. Brain Research 892 $255-262$.

Banerjee PP, Banerjee S, Tilly KI, Tilly JL, Brown TR \& Zirkin BR 1995 Lobe-specific apoptotic cell death in rat prostate after androgen ablation by castration. Endocrinology 136 4368-4376.

Brunk U, Jones CB \& Sohal RS 1992 A novel hypothesis of lipofuscinogenesis and cellular aging based on interactions between oxidative stress and autophagocytosis. Mutation Research 275 395-403.

Brunk U \& Terman A 2002 Lipofuscin: mechanisms of age-related accumulation and influence on cell function. Free Radical Biology and Medicine 33 611-619.
Chen H, Hardy MP, Huhtaniemi I \& Zirkin BR 1994 Age-related decreased Leydig cell testosterone production in the brown Norway rat. Journal of Andrology 15 551-557.

Clark G 1981 Staining Procedures, 4th edn. Baltimore, MD: Williams \& Wilkins.

Curtin JF, Donovan M \& Cotter TG 2002 Regulation and measurement of oxidative stress in apoptosis. Journal of Immunological Methods 265 49-72.

Fabregat I, Sanchez A, Alvarez AM, Nakamura T \& Benito M 1996 Epidermal growth factor, but not hepatocyte growth factor, suppresses the apoptosis induced by transforming growth factorbeta in fetal hepatocytes in primary culture. FEBS Letters $\mathbf{3 8 4}$ $14-18$.

Fan X \& Robaire B 1998 Orchidectomy induces a wave of apoptotic cell death in the epididymis. Endocrinology 139 2128-2136.

Gooren L 2003 Androgen deficiency in the aging male: benefits and risks of androgen supplementation. Journal of Steroid Biochemistry and Molecular Biology 85 349-355.

Higami Y \& Shimokawa I 2000 Apoptosis in the aging process. Cell and Tissue Research 301 125-132.

Jervis KM \& Robaire B 2002 Changes in gene expression during aging in the Brown Norway rat epididymis. Experimental Gerontology 37 897-906.

Kagan VE, Gleiss B, Tyurina YY, Tyurin VA, Elenstrom-Magnusson C, Liu SX, Serinkan FB, Arroyo A, Chandra J, Orrenius S \& Fadeel B 2002 A role for oxidative stress in apoptosis: oxidation and externalization of phosphatidylserine is required for macrophage clearance of cells undergoing fas-mediated apoptosis. Journal of Immunology 169 487-499.

Kasten FH 1981 Methods for fluorescent microscopy. In Staining procedures, 4th edn, p 53. Ed G Clark. London: Williams \& Wilkins.

Kimura M, Itoh N, Takagi S, Sasao T, Takahashi A, Masumori N \& Tsukamoto T 2003 Balance of apoptosis and proliferation of germ cells related to spermatogenesis in aged men. Journal of Andrology 24 185-191.

Levy S \& Robaire B 1999 Segment-specific changes with age in the expression of junctional proteins and the permeability of the blood-epididymis barrier in rats. Biology of Reproduction 60 $1392-1401$.

Levy S, Serre V, Hermo L \& Robaire B 1999 The effects of aging on the seminiferous epithelium and the blood-testis barrier of the Brown Norway rat. Journal of Andrology 20 356-365.

Morley JE \& Perry HM 2003 Androgen treatment of male hypogonadism in older males. Journal of Steroid Biochemistry and Molecular Biology 85 367-373.

Nakae Y, Stoward PJ, Shono M \& Matsuzaki T 2001 Most apoptotic cells in mdx diaphragm muscle contain accumulated lipofuscin. Histochemistry and Cell Biology 115 205-214.

Niu Y, Xu Y, Zhang J, Bai J, Yang H \& Ma T 2001 Proliferation and differentiation of prostatic stromal cells. British Journal of Urology International 87 386-393.

Samanta L, Roy A \& Chainy GB 1999 Changes in rat testicular antioxidant defence profile as a function of age and its impairment by hexachlorocyclohexane during critical stages of maturation. Andrologia 31 83-90.

Serre V \& Robaire B 1998 Segment-specific morphological changes in aging Brown Norway rat epididymis. Biology of Reproduction 58 497-513.

Silva IS, Morsch DM, Urnauer L \& Spritzer PM 2001 Androgeninduced cell growth and c-myc expression in human non-transformed epithelial prostatic cells in primary culture. Endocrine Research 27 153-169.

Sitte N, Huber M, Grune T, Ladhoff A, Doecke WD, Von Zglinicki T \& Davies KJ 2000 Proteasome inhibition by lipofuscin/ceroid during postmitotic aging of fibroblasts. FASEB Journal 14 1490-1498.

Steiner RA, Bremner WJ, Clifton DK \& Dorsa DM 1984 Reduced pulsatile luteinizing hormone and testosterone secretion with aging in the male rat. Biology of Reproduction 31 251-258. 
Tenover JL 1999 Testosterone replacement therapy in older adult men. International Journal of Andrology 22 300-306.

Terman A \& Brunk UT 1998 Ceroid/lipofuscin formation in cultured human fibroblasts: the role of oxidative stress and lysosomal proteolysis. Mechanisms of Ageing and Development 104 277-291.

Tsuji M, Terada N, Sugihara A, Tsujimura T, Donjacour AA \& Cunha GR 1998 Later onset of apoptosis in the bulbourethral glands after castration compared to that in the seminal vesicles. Journal of Steroid Biochemistry and Molecular Biology 67 113-118.

Turner TT, Jones CE, Howards SS, Ewing LL, Zegeye B \& Gunsalus GL 1984 On the androgen microenvironment of maturing spermatozoa. Endocrinology 115 1925-1932.

Vanderschueren D, Vandenput L, Boonen S, Van Herck E, Swinnen JV \& Bouillon R 2000 An aged rat model of partial androgen deficiency: prevention of both loss of bone and lean body mass by low-dose androgen replacement. Endocrinology 141 $1642-1647$.

Viger RS \& Robaire B 1995 Gene expression in the aging brown Norway rat epididymis. Journal of Andrology 16 108-117.

Waltregny D, Leav I, Signoretti S, Soung P, Lin D, Merk F, Adams JY, Bhattacharya N, Cirenei N \& Loda M 2001 Androgen-driven prostate epithelial cell proliferation and differentiation in vivo involve the regulation of p27. Molecular Endocrinology 15 $765-782$.
Wang C, Sinha Hikim AP, Lue YH, Leung A, Baravarian S \& Swerdloff RS 1999 Reproductive aging in the Brown Norway rat is characterized by accelerated germ cell apoptosis and is not altered by luteinizing hormone replacement. Journal of Andrology $\mathbf{2 0}$ 509-518.

Warner HR 1999 Apoptosis: a two-edged sword in aging. Annals of the New York Academy of Sciences 887 1-11.

Warner HR, Hodes RJ \& Pocinki K 1997 What does cell death have to do with aging? Journal of the American Geriatric Society $\mathbf{4 5}$ $1140-1146$.

Wyllie AH, Kerr JF \& Currie AR 1980 Cell death: the significance of apoptosis. International Review of Cytology 68 251-306.

Zirkin BR \& Chen H 2000 Regulation of Leydig cell steroidogenic function during aging. Biology of Reproduction 63 977-981.

Zirkin BR \& Strandberg JD 1984 Quantitative changes in the morphology of the aging canine prostate. Anatomical Record 208 $207-214$.

Received 19 June 2003

First decision 5 August 2003

Revised manuscript received 10 November 2003

Accepted 12 November 2003 